Ambiente \& Água - An Interdisciplinary Journal of Applied Science
ISSN 1980-993X - doi:10.4136/1980-993X
www.ambi-agua.net
E-mail: ambi.agua@gmail.com

\title{
Phytoplankton, Trophic State and Ecological Potential in reservoirs in the State of São Paulo, Brazil
}

\author{
ARTICLES doi:10.4136/ambi-agua.2428
}

Received: 20 Jun. 2019; Accepted: 30 Aug. 2019

\author{
Eduardo Henrique Costa Rodrigues ${ }^{1 *}$; Aline Martins Vicentin ${ }^{1}$; \\ Leila dos Santos Machado ${ }^{\text {DD }}$; Marcelo Luiz Martins Pompêo ${ }^{3}$; \\ Viviane Moschini Carlos 2 id
}

\author{
${ }^{1}$ Instituto de Ciência e Tecnologia, Programa de Pós-Graduação em Ciências Ambientais, \\ Universidade Estadual Paulista "Júlio de Mesquita Filho" (UNESP), Avenida Três de Março, n 511, \\ CEP 18087-180, Sorocaba, SP, Brazil. E-mail: line_vicentin@hotmail.com \\ ${ }^{2}$ Instituto de Ciência e Tecnologia, Departamento de Engenharia Ambiental, \\ Universidade Estadual Paulista "Júlio de Mesquita Filho" (UNESP), Avenida Três de Março, n 511, \\ CEP 18087-180, Sorocaba, SP, Brazil. E-mail: leila_snt@hotmail.com, viviane.moschini@unesp.br \\ ${ }^{3}$ Instituto de Biociências (IB), Programa de Pós-Graduação em Ecologia, Departamento de Ecologia, \\ Universidade de São Paulo (USP), Rua do Matão, Travessa 14, nº 321, CEP 05508-000, São Paulo, SP, Brazil. \\ E-mail: mpompeo@ib.usp.br \\ *Corresponding author. E-mail: edu_ufma@hotmail.com
}

\begin{abstract}
This study evaluated the ecological potential of reservoirs in the Brazilian state of São Paulo, having phytoplankton as a biological quality element. Integrated water column sampling was carried out in the dam, and in the intermediate and fluvial zones of the Igaratá, Atibainha, Paiva Castro, Rio Grande, Itupararanga, Broa, Barra Bonita, Guarapiranga and Salto Grande reservoirs in July 2015. Physico-chemical and biological parameters were analyzed in all environments. The phytoplankton was analyzed under an inverted microscope, and measurements of density, diversity, equitability and dominance were determined. The data was ordered using PCA and CCA analysis. The ecological potential of the reservoirs was determined through the evenness index. The electrical conductivity, nitrate, nitrite and orthophosphate were higher in the more eutrophic reservoirs: Salto Grande, Barra Bonita, Guarapiranga and Rio Grande. A trophic gradient was observed among the sampling points, suggesting a conservation spectrum. There was dominance of cyanobacteria in the eutrophic reservoirs associated with low diversity and high dominance. The total density was correlated with $\mathrm{TP}, \mathrm{TN}$, and $\mathrm{pH}$. A divergent relationship between the trophic state index and the evenness index was observed. The Atibainha, Itupararanga, Broa, Barra Bonita and Salto Grande reservoirs were classified as water bodies of very poor ecological quality (Bad). The evenness index seems to be a good alternative to the biomonitoring of the studied reservoirs.
\end{abstract}

Keywords: eutrophication, pollution, water quality.

\section{Fitoplâncton, Estado Trófico e Potencial Ecológico em Reservatórios do Estado de São Paulo, Brasil}

\section{RESUMO}

O objetivo deste trabalho foi estabelecer Potencial Ecológico de alguns reservatórios do 
estado de São Paulo, tendo como elemento de qualidade biológica o fitoplâncton. Amostras de água integrando a coluna d'água foram tomadas nas zonas lótica, central e de barragem dos reservatórios Igaratá, Atibainha, Paiva Castro, Rio Grande, Itupararanga, Broa, Barra Bonita, Guarapiranga e Salto Grande em julho de 2015. Paramentos físico-químicos e biológicos da água foram analisados em todos os ambientes. O fitoplâncton foi analisado sob microscópio invertido e medidas de densidade, diversidade, equitabilidade e dominância foram determinadas. A ordenação dos dados ocorreu através de uma PCA e uma CCA. O Potencial Ecológico dos reservatórios foi determinado por meio do Evenness E2 Index. A condutividade elétrica, nitrato, nitrito e ortofosfato foram maiores nos reservatórios mais eutrofizados, ou seja, Salto Grande, Barra Bonita, Guarapiranga e Rio Grande. Um gradiente trófico foi observado entre os pontos amostrais o que sugere um espectro de conservação. Houve dominância de cianobactérias em reservatórios eutrofizados associada a baixa diversidade e elevada dominância. A densidade total foi relacionada aos PT, NT e pH. Uma relação divergente entre os Índice do Estado Trófico e o Evenness E2 Index foi observada. Os reservatórios Atibainha, Itupararanga, Broa, Barra Bonita e Salto Grande foram classificados integralmente como corpos d'água de péssima qualidade ecológica (Bad). O Evenness E2 Index apresentou-se como uma boa alternativa ao biomonitoramento dos reservatórios investigados.

Palavras-chave: eutrofização, poluição, qualidade da água.

\section{INTRODUCTION}

In recent years the water quality of reservoirs has been significantly affected by human activities, increasing the frequency of impacts related to pollution and contamination. These impacts lead to eutrophication, resulting in loss of water quality and permanent change in the trophic condition of these environments, making them eutrophic. The effects of eutrophication are well known in the scientific world and affect mainly the productivity of aquatic environments. In eutrophic environments, phytoplankton is among the most-affected organisms, undergoing changes in their dynamics and ecological structure. These organisms represent an important element of aquatic ecosystems, playing a central role in their structure and functioning. Phytoplankton responds rapidly to any change in the environmental characteristics of an ecosystem, mainly to nutrient concentrations, and has been widely used in water monitoring studies (Vicentin et al., 2018; Batista and Fonseca, 2018; Moschini-Carlos et al., 2017; Tucci et al., 2009).

The quality of the water bodies in Brazil is evaluated according to standards established by the National Policy of Water Resources through Law No 9.433/1997 (Brasil, 1997), which promotes the management of national water resources. According to this law, a diagnosis of the current state of water resources must be carried out by monitoring the quality of the water bodies. This monitoring is based on the parameter quality limits according to CONAMA Resolution 357/2005 (CONAMA, 2005). According to this resolution, the phytoplankton is analyzed considering the density of cyanobacteria and the concentration of chlorophyll a in the water. In the member states of the European Union (EU), the process of management of water resources, river basins and monitoring of water bodies follows the European Water Framework Directive (WFD) (EC, 2000). The WFD adopts an ecosystem approach in a way that the water bodies will reach a state of minimum degradation. To do so, monitoring of inland water bodies using biological groups is required, and the phytoplankton represents one of these groups. When the physical, chemical, hydromorphological and biological conditions are good, they have a slight deviation from the conditions of the water body without anthropic pressures (Acreeman and Ferguson, 2010). The objective of the WFD is to achieve good ecological potential and good chemical status of surface waters, i.e., good condition, taking into account the uses for which these water bodies were created. Due to the operation and complexity of the uses, 
reservoir studies are necessary for a better understanding of the structure of the phytoplankton community, which is subject to the effects of eutrophication. This study established the ecological potential of nine reservoirs in the Brazilian state of São Paulo, using phytoplankton as a biological quality element, through the application of the evenness index.

\section{MATERIALS AND METHODS}

Nine reservoirs (Table 1) were studied in different regions of the Brazilian state of São Paulo. These reservoirs are formed by different water-producing systems and have multiple uses such as recreation, electricity generation, irrigation, nautical uses and public water supply. Sampling occurred in July 2015 during winter, in the dry season. In each reservoir three sampling points were chosen. The sampling points were distributed between the dam, intermediate and fluvial zones. For all the parameters, including phytoplankton, a single integrated water column sample was collected, considering 2.7 times the depth of Secchi (m) (Cole, 1994). Besides depth (m), the following parameters were determined in situ with the aid of a multiparameter probe YSI 556: SPM, surface temperature $\left({ }^{\circ} \mathrm{C}\right)$, dissolved oxygen $(\mathrm{mg} \mathrm{L}-$ 1), electrical conductivity ( $\mu \mathrm{S} \mathrm{cm}-1)$ and the $\mathrm{pH}$ of the water. Concentrations of nitrite (NO2-) and nitrate (NO3-) (Mackereth et al., 1978), ammonium (NH4+) (Koroleff, 1976), total nitrogen (TN) and total phosphorus (TP) (Valderrama, 1981), orthophosphate (P-orto) (Strickland and Parsons, 1960) and chlorophyll-a and phaeopigments (Lorenzen, 1967; Wetzel and Likens, 1991) were determined in the laboratory.

Table 1. Hydrological characterization of the nine reservoirs studied in the state of São Paulo. Area: Lake area in $\mathrm{km}^{2}$; Prof.: average depth (m); Vol. Volume (m3); R.T. residence time (days), Alt. Altitude (m).

\begin{tabular}{|c|c|c|c|c|c|c|}
\hline Reservoirs & Area & Depth & Vol. & R.T. & Alt. & Source \\
\hline Broa & 6.8 & 3 & $22 \times 10^{6}$ & $20-40$ & 712 & Cervi et al. (2017); \\
\hline Barra Bonita & 324.84 & 25 & $3160 \times 10^{6}$ & 100 & 451 & Cunha et al. (2013); Tundisi et al. (2008) \\
\hline Atibainha & 21.8 & 12.5 & $95,26 \times 10^{6}$ & 105,8 & 793 & Barros (2010) \\
\hline Paiva Castro & 5.1 & 13 & $7,0 \times 10^{6}$ & 1 & 753 & Pires et al. (2015) \\
\hline Rio Grande & 7.4 & 10 & $1,1 \mathrm{E}+08$ & 319 & 752 & $\begin{array}{l}\text { Cunha et al. (2013); Beyruth and Pereira } \\
\text { (2002) }\end{array}$ \\
\hline Itupararanga & 29.9 & 7.8 & $286 \times 10^{6}$ & 250 & 841 & Smith and Barrella, 2000 \\
\hline Igaratá* & 60.5 & 14.2 & $1,4 \mathrm{E}+06$ & 306 & 621 & Soares et al. (2015) \\
\hline Guarapiranga & 33 & 3.5 & $194 \times 10^{6}$ & 145 & 738 & Cunha et al. (2013); Pires et al. (2015) \\
\hline Salto Grande & 11.5 & 19 & $106 \times 10^{6}$ & 30 & 538 & $\begin{array}{l}\text { Martins et al. (2011); Hofling et al. (2000); } \\
\text { Zanata and Espindola (2002) }\end{array}$ \\
\hline
\end{tabular}

\subsection{Phytoplankton Analysis and Ecological Potential}

Regarding the qualitative analysis, the samples were collected with a $20 \mu \mathrm{m}$ mesh net by horizontal trawls at the surface. The material was identified following specialized bibliography: (Ramos et al., 2015a; 2015b; Alves-Da-Silva et al., 2013; Tucci et al., 2006; Sant'anna and Azevedo, 2000). The organisms were counted using the method described by Utermöhl (1958). Equitability ( $\mathrm{J}$ '), specific richness (S), and specific diversity were determined using the software PAST (Hammer, 2001). Dominant species were determined according to Lobo and Leighton (1986). The ecological potential of the reservoirs was determined through the evenness index (Spatharis and Tsirtsis, 2010). Evenness Index formula (Equation 1):

Evenness Index $=\frac{E X P\left(H^{\prime}\right)}{S}$ 
Where: $H^{\prime}$ is the Shannon-Weaver Index, and $\mathrm{S}$ is the number of species in a sample or population. The limits for the different ecological status classes according to the WFD were: Bad (0.0 - 0.2); Poor; (0.2 - 0.4) Moderate (0.4 - 0.6), Good (0.6 - 0.8) and High (0.8 - 1.0).

\subsection{Data analysis}

The trophic state index (TSI) was determined according to Lampareli (2004). The following classification was considered: ultraoligotrophic $(\mathrm{TSI} \leq 47)$; oligotrophic $(47<\mathrm{TSI} \leq$ 52); mesotrophic $(52<\mathrm{TSI} \leq 59)$, eutrophic $(59<\mathrm{TSI} \leq 63)$; supereutrophic $(63<\mathrm{TSI} \leq 67)$ and hypereutrophic (TSI > 67). A Principal Component Analysis (PCA) was performed using PAST software (Hammer, 2001). The PCA aimed to verify the ordering of the sampling points regarding the phytoplankton and the environmental variables for the reservoirs. Abiotic and biotic limnological variables were standardized through Z-score transformation. The ordering of the sampling points, through canonical correspondence analysis (CCA) was performed using the dominant species and environmental variables. For the CCA, the transformation was applied through the square root of the data of the species.

\section{RESULTS AND DISCUSSION}

A total of 196 species distributed into 99 genera were identified in this study, which suggests a very diversified phytoplankton community. Although the specific richness shows the predominance of green algae (26\%), the dominant group in terms of abundance was Cyanophyta. This result is similar to that found by other authors in Brazilian reservoirs: Adloff et al. (2018); Batista and Fonseca (2018); Silva et al. (2014); Soares et al. (2012); Cunha and Calijuri, (2011); Souza and Fernandes (2009). In addition, the highest values of density were observed where the concentration of nutrients was higher and where there was a high degree of eutrophication (Table 2).

Table 2. Total Density ( $\times 10^{3}$ cel. $\left.1^{-1}\right)$, of the phytoplankton in the different zones in reservoirs in the state of São Paulo. IGA (Igaratá), ATB (Atibainha), PC (Paiva Castro), RG (Rio Grande), ITUP (Itupararanga), BR (Broa/ Carlos Botelho), BB (Barra Bonita), GUA (Guarapiranga), SG (Salto Grande).

\begin{tabular}{cccccccccc}
\hline Zone & IGA & ATI & PC & RG & ITUP & BR & BB & GUA & SG \\
\hline River & 1.167 & 55.024 & 616.243 & 5.077 & 116.204 & 345.181 & 211.246 & 37.699 & 406.250 \\
Cent & 1.414 & 42.438 & 602.982 & 8.047 & 35.746 & 239.298 & 1.251 .650 & 79.446 & 518.047 \\
Dam & 1.212 & 55.923 & 885.949 & 10.027 & 86.595 & 150.699 & 758.509 & 396.396 & 36.550 \\
\hline
\end{tabular}

The variation of diversity, equitability and dominance indexes followed the degree of conservation of the reservoirs, with the lowest values of diversity and equitability being recorded in the most eutrophic reservoirs (Figure 1). The dominance was higher in eutrophic reservoirs reflecting the impact caused by the share of cyanobacteria in phytoplankton. The low diversity values observed in Broa, Barra Bonita, Itupararanga and Salto Grande reservoirs may be directly related to the dominance of Microcystis aeruginosa. In these same reservoirs, a lower richness was also observed, and high values of density (Figure 1).

The dominance of cyanobacteria forming dense blooms has been particularly useful as an indicator of high nutritional status (Bellinger and Sigee, 2010). Our results have suggested the formation of monospecific blooms of Microcystis aeruginosa in Broa (supereutrophic to eutrophic), Barra Bonita (supereutrophic to eutrophic) and Salto Grande (supereutrophic to hypereutrophic) reservoirs. These results have already been presented in previous studies, 
including records of other species blooms, such as Cylindrospermopsis raciborskii, Microcystis spp and Coelosphaerium evidenter-maginatum in Broa (Tundisi et al., 2015), Barra Bonita (Bittencourt-Oliveira, 2003) and Salto Grande (Fonseca, 2014) reservoirs, respectively. The high density of cyanobacteria may lead to problems of water quality since several genera can produce potent cyanotoxins, which are harmful to human health (Fotiou et al., 2016). The following genera with toxic potential were registered in this study: Aphanizomenon, Cylindrospermopsis, Microcystis, Dolichosperum (Anabaena) and Oscillatoria.

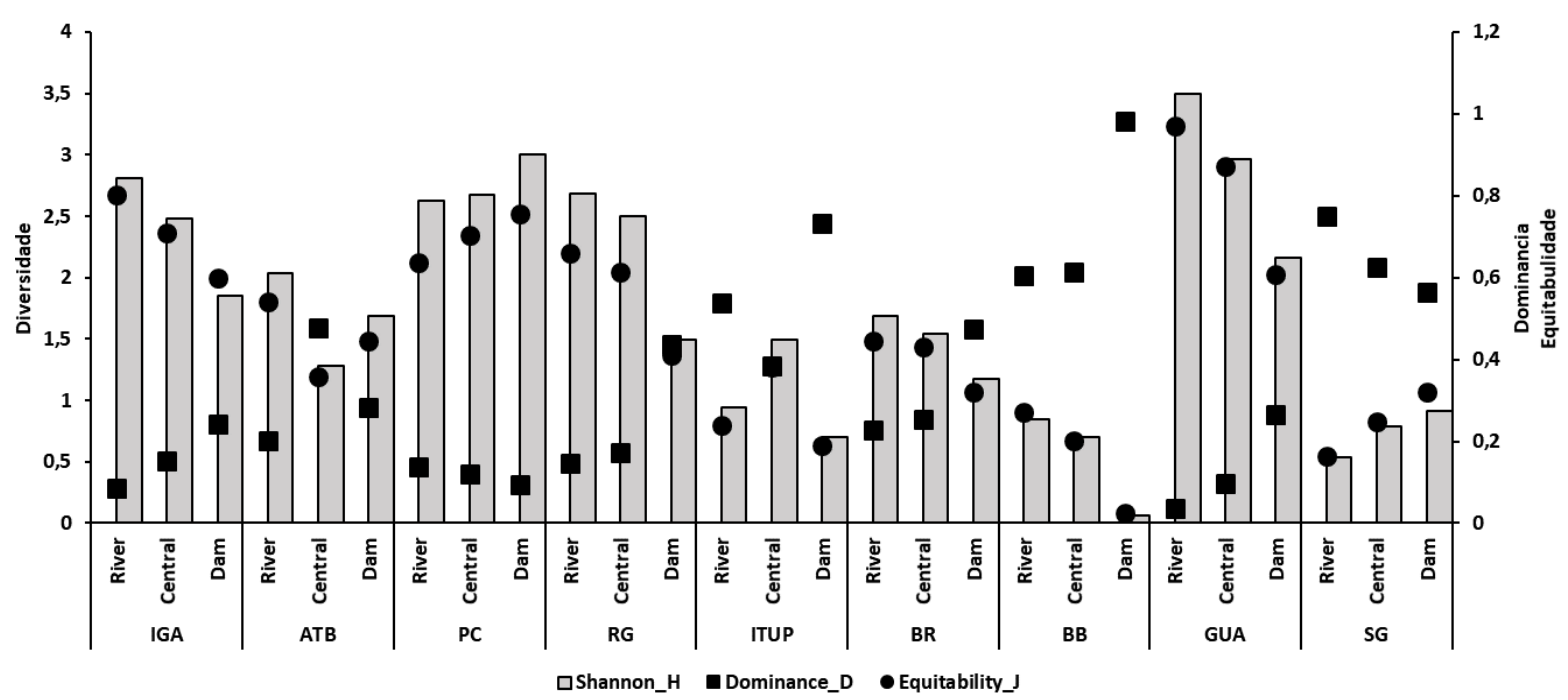

Figure 1. Diversity (bits.cel ${ }^{-1}$ ), equitability and dominance of phytoplankton in reservoirs in the state of São Paulo. IGA (Igaratá), ATB (Atibainha), PC (Paiva Castro), RG (Rio Grande), ITUP (Ituparanga), BR (Broa/ Carlos Botelho), BB (Barra Bonita), GUA (Guarapiranga), SG (Salto Grande).

The clustering of points with the same trophic state presented in the PCA (Figure 2), showed a trophic gradient, gathering environments with trophic status ranging from oligotrophic to hypereutrophic. The parameters most correlated to the first two axes are the same parameters associated in the determination of the trophic state of the investigated environments, which validates the PCA results. The total density of the phytoplankton regarding the Barra Bonita reservoir highlight the importance of this parameter in that environment, since some of the highest density values and inorganic nutrient concentrations (mainly NH4) were recorded in this reservoir (Table 1). The points located in the reservoirs classified as supereutrophic and hypereutrophic were correlated with the parameters DO (dissolved oxygen), Dens (density), pH, TP (total phosphorus), TN (total nitrogen), SS (suspended solids), and EC (electrical conductivity) (Figure 2). The Igaratá, Atibainha, Itupararanga, Paiva Castro and Rio Grande reservoirs were grouped together; these reservoirs were correlated with depth and transparency, which is confirmed by the hydrological characteristics of these environments. The sampling points in the Barra Bonita, Salto Grande, Guarapiranga and Broa reservoirs were located close to each other. These environments were correlated with phytoplankton density, water temperature, $\mathrm{pH}$, dissolved oxygen concentration, total nitrogen and phosphorus, suspended solids and electrical conductivity. The sampling points located in the Paiva Castro, Rio Grande and Itupararanga reservoirs are located in a position that indicates a transition between mesotrophic, eutrophic and super eutrophic environments; this position is intermediate between oligo-mesotrophic and superhypereutrophic reservoirs. Axis 01 was correlated with the parameters TN (0.48), TP (0.43), SS (0.45), SD (-0.36) $\mathrm{pH}(0.23)$ while Axis 02 was more correlated with TEMP (0.56), DO (0.64), EC (-0.43), and DENS (0.16) (Figure 2). 


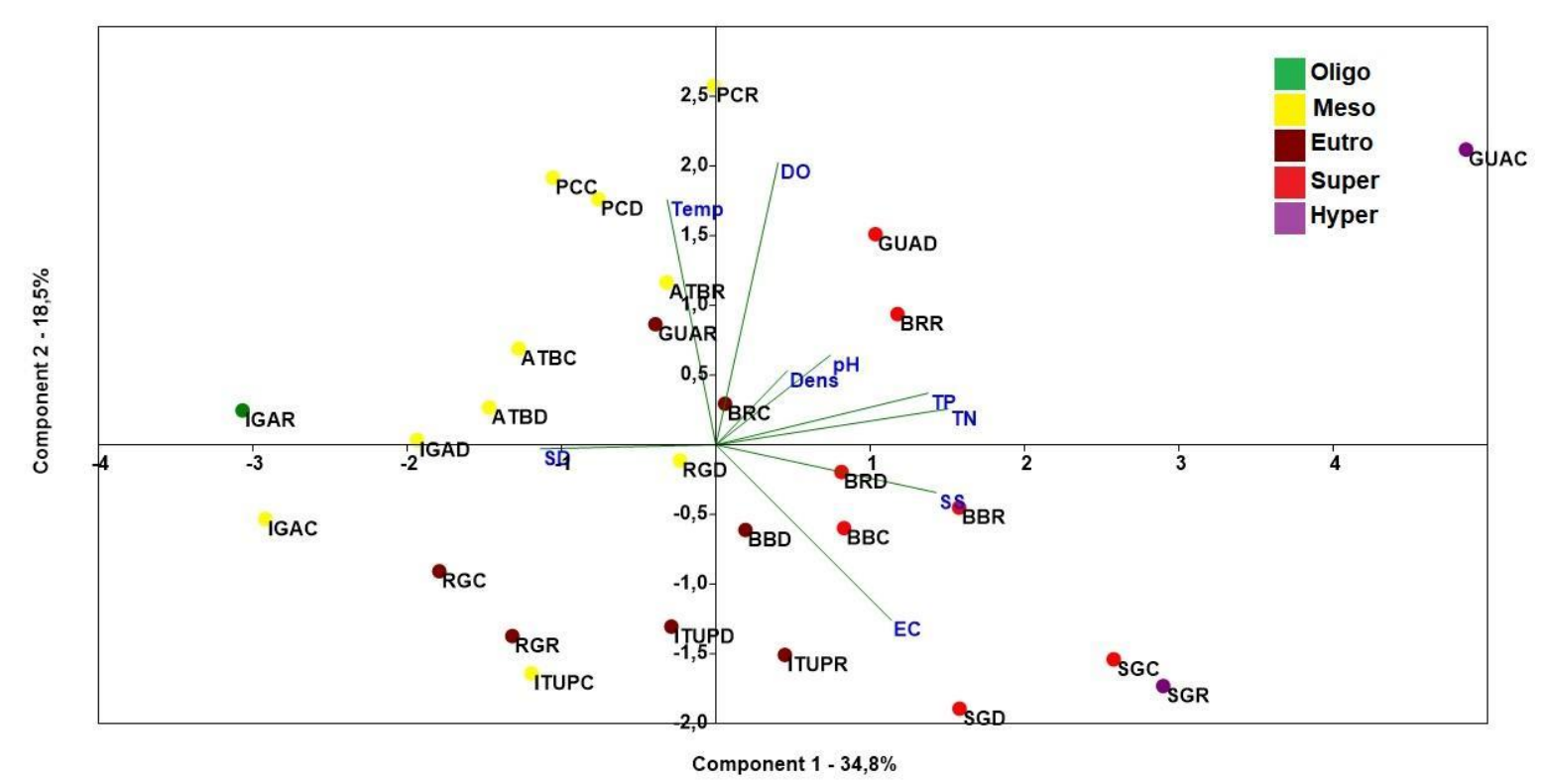

Figure 2. Principal Component Analysis Diagram (PCA), with the ordering of the sampling points in the different reservoirs, density scores and environmental variables. Limnological variables: Temp., temperature; $\mathrm{pH}$, TN, total nitrogen; TP, total phosphorus, SS suspended solids; DO Dissolved oxygen; SD, Secchi; EC, Electric conductivity.

The Canonical Correspondence Analysis (CCA), performed with the environmental parameters and the species density of the 12 dominant species, presented an eigenvalue of 0.99 , explaining $20.7 \%$ of the variation, while in the second axis it has an eigenvalue of 0.97 , explaining $40.9 \%$ of the variation (Table 2). The correlation between density and the environmental parameters was considered strong, 0.99 for the first axis, and 0.98 for the second axis. The first axis was correlated with transparency, temperature, nutrients (TP and TN), suspended solids (SS), electrical conductivity (EC) and dissolved oxygen concentration (OD) (Figure 3a). The second axis was more correlated with $\mathrm{pH}$. The association with the parameters and the sampling points in each reservoir evidenced by the CCA corroborated with the limnological characteristics of each environment investigated. A massive clustering of sample points from all reservoirs can be observed in the central part of the CCA diagram. Some dispersed points were observed: Igaratá (2), Rio Grande (10-11) and Guarapiranga (23) (Figure 3a). The species were distributed according to their prominent position in the studied reservoirs (Figure 3b), showing similar ordering to sampling points. According to the CCA, SD (transparency) seems to be the most important variable for variability of dominant species in the studied environments. Pseudanabaena galeata Böcher was correlated with the reservoir that had the highest trophy level (Rio Grande), where it was dominant. Eudorina sp was correlated with Igaratá Reservoir. Synechocystis aquatilis Sauvageau and Planktolyngbya limnetica (Lemmermann) Komárková-Legnerová \& Cronberg were correlated to Guarapiranga Reservoir.

The cyanobacteria Konvophorum sp, Pseudanabaena galeata, Cylindrospermopsis raciborskii and Merismopedia glauca and the green seaweed Eudorina illinoisensis were more correlated with the reservoirs classified as oligo-mesotrophic (Figure 3b). The correlation of the dinoflagellate Ceratium furcoides with the lower trophic state reservoirs was due to the dominance of this organism in Igaratá and Atibainha Reservoirs. The cyanobacteria Microcystis aeruginosa, Microcystis panniformis, Synechocystis aquatilis, Planktothrix agardhii, Aphanizomenon gracile were correlated with the most eutrophic reservoirs: Broa, Barra Bonita, Guarapiranga and Salto Grande (Figure 3b). 

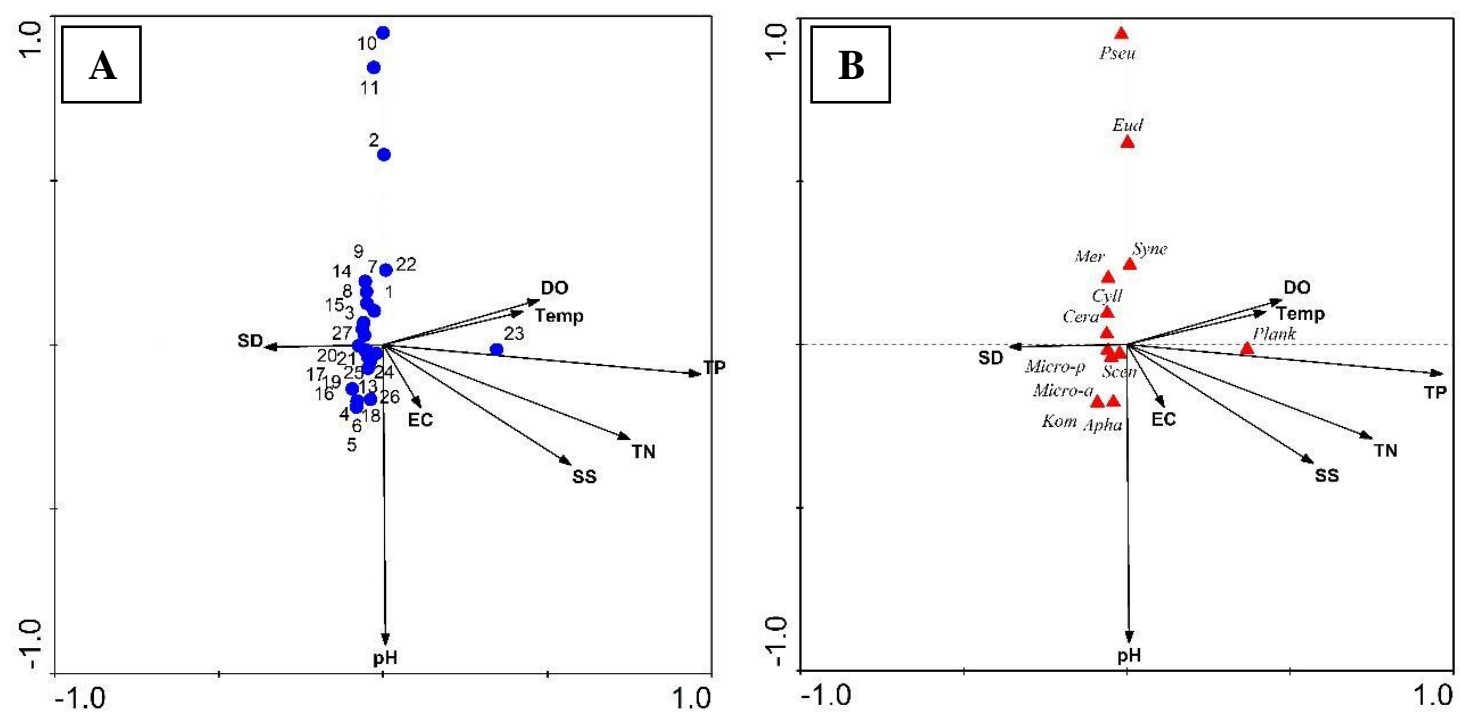

Figure 3. Ordering the samples corresponding to the different zones and reservoirs studied through biplots of the Canonical Correspondence Analysis (CCA) (A) biplot between variables and sampling points reservoirs (B) biplot between species and environmental variables.

The classification of the ecological potential of the reservoirs, evaluated through the evenness index, directly affected the environmental quality of these environments. In general, the reservoirs characterized by high trophy levels obtained the worst classifications, while the less eutrophic reservoirs had better classifications (Figure 4). Overall, the limnological variables indicate that the studied reservoirs are impacted or in the process of degradation, corroborating the scenario described for these environments in Figure 4. The results of the present study showed that the Ituraranga, Broa, Barra Bonita and Salto Grande reservoirs are among the most impacted environments, with high concentrations of inorganic nutrients and chlorophyll a, as well as a high eutrophic level. These reservoirs are located in basins with high level of anthropic impacts, and this directly affects the limnological characteristics of the reservoirs; for example, in Bonita Barra, reservoirs blooms of Microcystis $s p$ and other potentially toxic cyanobacteria are common (Tundisi et al., 2008; Sotero-Santos et al., 2006). The Salto Grande reservoir, located in the central-eastern region of the State of São Paulo, is located in the Atibaia River basin, that has high urban and industrial density (Zanata and Espíndola, 2002), and there are also contributions from several small tributaries draining the urban centers (Rietzler et al., 2018). In the region where Barra Bonita Reservoir is located, there is a strong anthropogenic pressure due to intense industrial activities (Petesse et al., 2007), being considered one of the most populous and industrialized areas in the state of São Paulo (Rietzler et al., 2018).

The evenness index was a good response to the reality of the Brazilian reservoirs, but a divergence between the TSI and the evenness index can be observed in the Atibainha (mesotrophic) and Guarapiranga (super-hypereutrophic) reservoirs. That was probably motivated by modifications in the phytoplankton community structure caused by different phenomena, of natural or anthropic origin. In Guarapiranga Reservoir the changes may be related to the management measures regarding the use of raw water, while in Atibainha, changes in the reservoir level during the atypical drought of 2013-2015 may also have affected phytoplankton structure in this environment.

In reservoirs, water level fluctuations, as well as changes in hydraulic conditions, are factors that affect phytoplankton structure (Tucci et al., 2009). The reduction of the water volume affects the concentration of nutrients and material, and there is also a decrease in the current velocity (Granado et al., 2009). These changes may be the main factors controlling the 
development and composition of algae (Martinet et al., 2014), as well as the density and richness of phytoplankton. In our studies, this may have been directly reflected in the ecological potential, since these metrics (richness and density) are important for the determination of the evenness index. In the case of the Guarapiranga Reservoir, raw water management measures, with application of algicides, may have influenced the divergence between the trophic state indices and the ecological potential. Due to the high eutrophic level, Guarapiranga has frequent blooms (Ogashawara et al., 2014), which led to the application of algicide, decreasing the density of phytoplankton, mainly cyanobacteria, as the index represents a direct relation between richness and density. The increase or decrease in density implied significant changes in the index response in this environment. However the trophic condition of this reservoir remains the same, which could imply in new cases of blooms, therefore increasing the application of algicides.

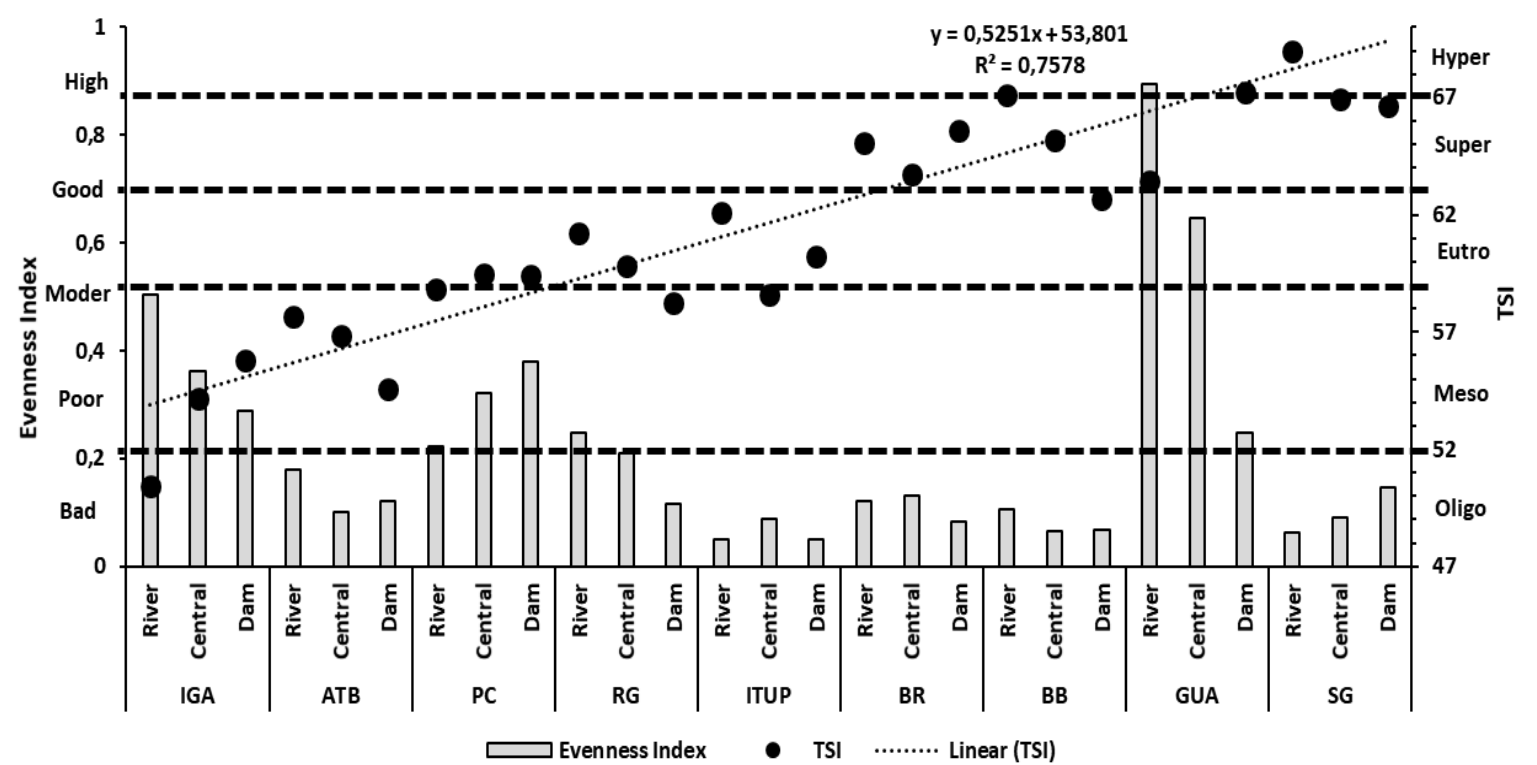

Figure 4. Variation of the evenness index and ecological potential in reservoirs in the state of São Paulo. IGA (Igaratá), ATB (Atibainha), PC (Paiva Castro), RG (Rio Grande), ITUP (Ituparanga), BR (Broa/ Carlos Botelho), BB (Barra Bonita), GUA (Guarapiranga), SG (Salto Grande).

\section{CONCLUSIONS}

The trophic gradient observed among the studied reservoirs reflected directly on the biological quality of these environments, affecting the phytoplankton structure (density, richness, diversity and evenness), this result was accompanied by the scenario shown by the evenness index, which uses diversity $\left(\mathrm{H}^{\prime}\right)$ as the main metric. This gradient suggests a scenario of the conservation status of these environments and what can be anticipated regarding the limnological characteristics of these reservoirs. In our study, diversity was negatively affected by the eutrophication process. In this sense, this index has become a particularly useful tool for assessing the ecological potential of reservoirs, since the ecological quality of the aquatic environment is a consequence of its conservation status, which in turn is affected by the eutrophication process. The Evenness Index responded well to the reservoirs and works as a complementary measure to the biomonitoring of these reservoirs; however, other components are still needed. The use of means of evaluation is suggested for a better understanding of ecological information and monitoring in reservoirs. The Evenness Index is a tool that could help the decision makers with better management measures. 


\section{REFERENCES}

ACREEMAN, M. C.; FERGUSON, J. D. Environmental ûows and the European Water Framework Directive. Freshwater Biology, v. 55, p 32-48, 2010. https://doi.org/10.1111/j.1365-2427.2009.02181.x

ADLOFF, C. T.; BEM, C. C.; REICHERT, R.; AZEVEDO, J. C. R. Analysis of the phytoplankton community emphasizing cyanobacteria in four cascade reservoirs system of the Iguazu River, Paraná, Brazil. Revista Brasileira de Recursos Hídricos, v. 23, n. 6, 2018. http://dx.doi.org/10.1590/2318-0331.0318170050

ALVES-DA-SILVA, S. M.; CABREIRA, J. C.; VOOS, J. G.; LOBO, E. A. Species richness of the genera Trachelomonas and Strombomonas (pigmented Euglenophyceae) in a subtropical urban lake in the Porto Alegre Botanical Garden, RS, Brazil. Acta Botanica Brasilica, v. 27, n. 3, p. 526-536, 2013. http://dx.doi.org/10.1590/S010233062013000300010

BATISTA, B. D.; FONSECA, B. M. Fitoplâncton da região central do Lago Paranoá (DF): uma abordagem ecológica e sanitária. Engenharia Sanitária e Ambiental, v. 23, n. 2, p. 229241, 2018. http://dx.doi.org/10.1590/s1413-41522018169124

BARROS, L. A. A. B. Uma história visual da construção do Sistema Cantareira. São Paulo: Autor, 2010. p. 15.

BELLINGER, E. G.; SIGEE, D. C. Freshwater algae: Identification and use as bioindicators. Oxford: Wiley-Blackwell, 2010. 271 p.

BEYRUTH, Z; PEREIRA, H. A. S. L. The isolation of Rio Grande from Billings Reservoir: effects on the phytoplankton. Boletim do Instituto de Pesca, v. 28, n. 2, p. 111 - 123, 2002.

BITTENCOURT-OLIVEIRA, M. C. Detection of potential microcystin-producing cyanobacteria in Brazilian reservoirs with a mcyB molecular marker. Harmful Algae, v. 2, p. 51-60, 2003. https://doi.org/10.1016/S1568-9883(03)00004-0

BRASIL. Presidência da República. Lei n. 9.433, de 9 de janeiro de 1997. Institui a Política Nacional de Recursos Hídricos, cria o Sistema Nacional de Gerenciamento de Recursos Hídricos, regulamenta o inciso XIX do art. 21 da Constituição Federal, e altera o art. $1^{\circ}$ da Lei $\mathrm{n}^{\circ}$ 8.001, de 13 de março de 1990, que modificou a Lei $\mathrm{n}^{\circ} 7.990$, de 28 de dezembro de 1989. Diário Oficial [da] União: seção 1, Brasília, DF, 09 jan. 1997.

CERVI, E. C.; FERNANDES, F.; MIRANDA, F. M.; MAUAD, F. M.; MICHALOVICZ, L.; POLETO, C. Geochemical speciation and risk assessment of metals in sediments of the Lobo-Broa Reservoir, Brazil. Management of Environmental Quality, v. 28, n. 3, p.430443, 2017.

COLE, G. A. Textbook of Limnology. Illinois: Waveland Press, 1994. 412 p.

CONAMA (Brasil). Resolução n 357 de 17 de março de 2005. Dispõe sobre a classificação dos corpos de água e diretrizes ambientais para o seu enquadramento, bem como estabelece as condições e padrões de lançamento de efluentes, e dá outras providências. Diário Oficial [da] União: seção 1, Brasília, DF, n. 053, p. 58-63, 18 mar. 2005.

CUNHA, D. G. F.; CALIJURI, M. C.; LAMPARELLI, M. C.; MENEGON J. R. N. Resolução CONAMA 357/2005: análise espacial e temporal de não conformidades em rios e reservatórios do estado de São Paulo de acordo com seus enquadramentos (2005-2009). Engenharia Sanitária e Ambiental, v.18, n. 2, p. 159-168, 2013. 
CUNHA, D. G. F.; CALIJURI, M. C. Variação sazonal dos grupos funcionais fitoplanctônicos em braços de um reservatório tropical de usos múltiplos no estado de São Paulo (Brasil). Acta Botanica Brasilica, v. 25, n. 4, p. 822-831, 2011.

EC. Directive 2000/60/EC of the European Parliament and of the Council of 23 October 2000 establishing a framework for community action in the field of water policy. Official journal of the European communities, L327, p. 1-72, 2000.

FONSECA, A. M. Cianobactérias e cianotoxinas em áreas recreacionais do Reservatório de Salto Grande, Americana - SP. 2014. 112f. Dissertação (Metrado em Microbiologia Agricola) - Escola Superior de Agricultura Luiz de Queiroz, Piracicaba, 2014.

FOTIOU, T.; TRIANTIS, T. M.; KALOUDIS, T.; O'SHEA, K. E.; DIONYSIOU, D. D.; HISKIA, A. Assessment of the roles of reactive oxygen species in the UV and visible light photocatalytic degradation of cyanotoxins and water taste and odor compounds using CTiO2. Water Research, v. 90, p. 52-61, 2016. https://doi.org/10.1016/j.watres.2015.12.006

GRANADO, D. C.; HENRY, R.; TUCCI, A. Influência da variação do nível hidrométrico na comunidade fitoplanctônica do Rio Paranapanema e de uma lagoa marginal na zona de desembocadura na Represa de Jurumirim (SP). Hoehnea, v. 36, n. 1, p. 113-129, 2009. http://dx.doi.org/10.1590/S2236-89062009000100006

HAMMER, Ø. D. Manual de Referência PAST: Paleontological Statistics Software Package for Education and Data Analysis. 2001. Available at: http://folk.uio.no/ohammer/past/ Access: 20 Apr. 2019.

HOFLING, J. C.; FERREIRA, L. I. RIBEIRO NETO, F. B.; BRUNINI, A. P. C. Ecologia trófica do reservatório de Salto Grande, Americana, SP, Brasil. Bioikos, v. 14, n. 1, p. 7-15, 2000.

KOROLEFF, M. Determination of nutrients. In: GRASSHOFF, K. (ed). Methods of sea water analysis. Weinhein: Verlag Chemie, 1976. p. 117-181.

LAMPARELLI, M. C. Graus de trofia em corpos d'água de estado de São Paulo: avaliação os métodos de monitoramento. 2004. 238f. Tese (Doutorado em Ecologia) - Instituto de Biociência, Universidade de São Paulo, São Paulo, 2004.

LORENZEN, C. J. Determination of chlorophyll and pheo-pigments: Spectrophotometric equations. Limnology and Oceanography, v. 12, p. 343-346, 1967.

LOBO, E.; LEIGHTON, G. Estructuras comunitárias de las fitocenosis planctónicas de los sistemas de desembocaduras de ríos y esteros de la zona central de Chile. Revista Biologia Marinha, v. 22, n. 1, p. 1-29, 1986.

MACKERETH, J. F. H.; HERON, J.; TALLING, J. F. Water analysis: some revised methods for limnologists. Freshwater Biological Association, v. 36, p. 121, 1978.

MARTINS, D.; MARCHI, S. R.; COSTA, N. V.; CARDOSO, L. A.; RODRIGUES-COSTA, A. C. Levantamento de plantas aquáticas no reservatório de Salto Grande, Americana-SP. Planta Daninha, v. 29, n. 1, p. 231-236, 2011. http://dx.doi.org/10.1590/S010083582011000100025

MARTINET, J.; DESCLOUX, S.; GUEDANT, P.; RIMET, F. Phytoplankton functional groups for ecological assessment in young sub-tropical reservoirs: case study of the NamTheun 2 Reservoir, Laos, South-East Asia. Journal of Limnology, v. 73, n. 3, p. 536550, 2014. https://doi.org/10.4081/jlimnol.2014.958 
MOSCHINI-CARLOS, V.; POMPÊO, M.; NISHIMURA, P. Y.; ARMENGOL, J. Phytoplankton as trophic descriptors of a series of Mediterranean reservoirs (Catalonia, Spain). Fundamental and Applied Limnology, v. 191, p. 37-52, 2017. https://doi.org/10.1127/fal/2017/1049

OGASHAWARA, I.; ALCANTARA, E. H.; STECH, J. L. TUNDISI, J. G. Cyanobacteria detection in Guarapiranga Reservoir (São Paulo State, Brazil) using Landsat TM and ETM+ images. Revista Ambiente \& Água, v. 9, n. 2, p. 224-238, 2014. http://dx.doi.org/10.4136/ambi-agua.1327

PETESSE, M. L.; PETRERE JR., M.; SPIGOLON, R. J. The hydraulic management of the Barra Bonita reservoir (SP, Brazil) as a factor influencing the temporal succession of its fish community. Brazilian Journal of Biology, v. 67, n. 3, p. 433-445, 2007. http://dx.doi.org/10.1590/S1519-69842007000300008

PIRES, D. A.; TUCCI, A. CARVALHO, M. C. LAMPARELLI, M. C. Water quality in four reservoirs of the metropolitan region of São Paulo, Brazil. Acta Limnologica Brasiliensia, v. 27, n. 4, p. 370-380, 2015. http://dx.doi.org/10.1590/S2179-975X4914

RAMOS, G. J. P.; BICUDO, C. E. M.; MOURA, C. W. N. Trebouxiophyceae (Chlorophyta) do Pantanal dos Marimbus, Chapada Diamantina, Bahia, Brasil. Iheringia Série Botânica, v. 70, n. 1, p. 57-72, 2015a.

RAMOS, G. J. P.; BICUDO, C. E. M.; MOURA, C. W. N. Scenedesmaceae (Chlorophyta, Chlorophyceae) de duas áreas do Pantanal dos Marimbus (Baiano e Remanso), Chapada Diamantina, Estado da Bahia, Brasil. Hoehnea, v. 42, n. 3, p. 549-566, 2015 b. http://dx.doi.org/10.1590/2236-8906-03/2015

RIETZLER, A. C.; BOTTA, C. R.; RIBEIRO, M. M.; ROCHA, O.; FONSECA, A. L. Accelerated eutrophication and toxicity in tropical reservoir water and sediments: an ecotoxicological approach. v. 25, n. 14, p. 13292-13311, 2018. https://doi.org/10.1007/s11356-016-7719-5

SANT'ANNA, C. L.; AZEVEDO, M. T. P. Contribution to the knowledge of potentially toxic Cyanobacteria from Brazil. Nova Hedwigia, v. 71, p. 359-385, 2000.

SILVA, L. H. S.; HUSZAR, V. L. M.; MARINHO, M. M.; RANGEL, L. M.; BRASIL, J.; DOMINGUES, C. D.; BRANCO, C. C.; ROLAND, F. Drivers of phytoplankton, bacterioplankton, and zooplankton carbono biomass in tropical hydroelectric reservoirs. Limnologica, v. 48, p. 1-10, 2014. https://doi.org/10.1016/j.limno.2014.04.004

SMITH, W. S.; BARRELLA, W. The ichthyofauna of the marginal lagoons of the sorocaba river, sp, Brazil: composition, abundance and effect of the anthropogenic actions. Revista Brasileira de Biologia, v. 60, n. 4, p. 627-632, 2000. http://dx.doi.org/10.1590/S003471082000000400012

SOARES, A. L.; MACHADO, R. M. A.; SEIXAS FILHO, J. T. O estado da arte do reservatório Jaguari no abastecimento da cidade do Rio de Janeiro. Semioses, v. 9, n. 2, p. 12-21, 2015.

SOARES, M. C. S.; MARINHO, M. M.; AZEVEDO, S. M. O. F.; BRANCO, C. W.C.; HUSZAR, V. L. M. Eutrophication and retention time affecting spatial heterogeneity in a tropical reservoir. Limnologica, v. 42, p. 197-203, 2012. https://doi.org/10.1016/j.limno.2011.11.002 
SOUZA, B. D.; FERNANDES, V. O. Estrutura e dinâmica da comunidade fitoplanctônica e sua relação com as variáveis ambientais na lagoa Mãe-Bá, Estado do Espírito Santo, Brasil Acta $\begin{array}{lllllllll}\text { Scientiarum. Biological Sciences, } & \text { v. 31, } & \text { n. } 3, & \text { p. 245-253, } 2009 .\end{array}$ https://dx.doi.org/10.4025/actascibiolsci.v31i3.1266

SOTERO-SANTOS, R. B.; SILVA, C. R. D. S.; VERANI, N. S. NONAKA, K. O.; ROCHA, O. Toxicity of a cyanobacteria bloom in Barra Bonita Reservoir (Middle Tietê River, São Paulo, Brazil). Ecotoxicology and Environmental Safety, v. 64, p. 163-170, 2006. https://doi.org/10.1016/j.ecoenv.2005.03.011

SPATHARIS, S.; TSIRTSIS, G. Ecological quality scales based on phytoplankton for the implementation of Water Framework Directive in the Eastern Mediterranean. Ecological Indicators, v. 10, n. 4, p. 840-847, 2010. https://doi.org/10.1016/j.ecolind.2010.01.005

STRICKLAND, J. D.; PARSONS, T. R. A manual of seawater analysis. Ottawa: The Fisheries Research Board, 1960. 185 p.

TUCCI, A.; GRANADO, D. C.; HENRY, R. Influência da variação do nível hidrométrico na comunidade fitoplanctônica do Rio Paranapanema e de uma lagoa marginal na zona de desembocadura na Represa de Jurumirim (SP). Hoehnea, v. 36, p. 113-129, 2009. http://dx.doi.org/10.1590/S2236-89062009000100006

TUCCI, A.; SANT'ANNA, C. L.; GENTIL, R. C.; AZEVEDO, M. T. P. Fitoplâncton do Lago das Garças, São Paulo, Brasil: um reservatório urbano eutrófico. Hoehnea, v. 33, n. 2, p. $147-$ $175,2006$.

TUNDISI, J. G.; MATSUMURA-TUNDISI, T.; ABE, D. S. The ecological dynamics of Barra Bonita (Tietê River, SP, Brazil) reservoir: implications for its biodiversity. Brazilian Journal of Biology, v. 68, n. 4, p. 1079-1098, 2008. http://dx.doi.org/10.1590/S151969842008000500015

TUNDISI, J. G.; MATSUMURA-TUNDISI, T.; TUNDISI, J. E. M.; BLANCO, F. P; ABE, D. S.; CONTRI CAMPANELLI, L.; SIDAGIS GALLI, G.; SILVA, V. T.; LIMA, C. P. P. A bloom of cyanobacteria (Cylindrospermopsis raciborskii) in UHE Carlos Botelho (Lobo/Broa) reservoir: a consequence of global change? Brazilian Journal of Biology, v. 75, n. 2, p. 507 508, 2015. http://dx.doi.org/10.1590/1519-6984.24914

UTERMOHL, H. Zur vervolkommung der quantitativen phytoplankton methodik. Mitteilungen Internationale Verein Limnologie, v. 9, p. 1-38, 1958.

VALDERRAMA, J. C. The simultaneous analysis of total nitrogen and phosphorus in natural waters. Marine Chemistry, v. 10, p. 109- 122, 1981. https://doi.org/10.1016/03044203(81)90027-X

VICENTIN, A. M.; RODRIGUES, E. H. C.; MOSCHINI-CARLOS, V.; POMPEO, M. L. M. Is it possible to evaluate the ecological status of a reservoir using the phytoplankton community? Acta Limnologica Brasiliensia, v. 30, p. 100, 2018.

WETZEL, R. G.; LIKENS, G. E. Limnological analyses. 20 ed. Springer-Verlag, 1991.

ZANATA, L. H.; ESPÍNDOLA, E. L. G. Longitudinal processes in Salto Grande reservoir (Americana, SP, Brazil) and its influence in the formation of compartment system. Brazilian Journal of Biology, v. 62, n. 2, p. 347-361, 2002. http://dx.doi.org/10.1590/S151969842002000200019 